\title{
Parietal cells in the duodenal bulb and their relation to Helicobacter pylori infection
}

\author{
A W Harris, M M Walker, A Smolka, J M Waller, J H Baron, J J Misiewicz
}

Parkside Helicobacter Study Group, Central Middlesex and St Mary's Hospitals,

London

A W Harris

M M Walker

J M Waller

J H Baron

J J Misiewicz

Medical University of South Carolina, Charleston, USA

A Smolka

Correspondence to:

Dr A W Harris,

Department of

Gastroenterology and

Nutrition,

Central Middlesex Hospital,

London NW10 7NS.

Accepted for publication

5 January 1996

\begin{abstract}
Aim-To investigate the prevalence, and relation to Helicobacter pylori, of parietal cells in the duodenal bulb using a monoclonal antibody directed against $\mathrm{H}^{+}, \mathrm{K}^{+}$ATPase (HK12.18).

Methods-Twenty six patients with duodenal ulcer disease and 16 healthy controls were studied. $H$ pylori status was determined by gastric histology and culture and by the ${ }^{13} \mathrm{C}$-urea breath test. Four biopsy specimens were taken from the duodenal bulb and stained with HK12.18. The presence/absence and number of parietal cells in the duodenal bulb were assessed blindly by a histopathologist.

Results-The overall prevalence of parietal cells in the duodenal bulb was $31 \%$ (13/42) and was similar in patients with duodenal ulcer and in controls, and in $H$ pylori positive and negative subjects. The median (range) number of parietal cells in the duodenal bulb was $7 \cdot 5(4-20)$ parietal cells/subject, and was similar in all four groups.

Conclusions-The prevalence of parietal cells in the duodenal bulb (31\%) is notably higher than previously reported in endoscopic studies, and is in keeping with reports from studies on necropsy/operative specimens. There was no difference in the prevalence or number of parietal cells in the duodenal bulb between patients with duodenal ulcer and controls, regardless of $H$ pylori status. These findings suggest that parietal cells in the duodenal bulb do not contribute to the pathogenesis of duodenal ulcer.

( $\mathcal{F}$ Clin Pathol 1996;49:309-312)
\end{abstract}

Keywords: Helicobacter pylori, duodenal ulcer, parietal cells, $\mathrm{H}^{+}, \mathrm{K}^{+}$-ATPase.

Table 1 Prevalence of parietal cells in the duodenal bulb

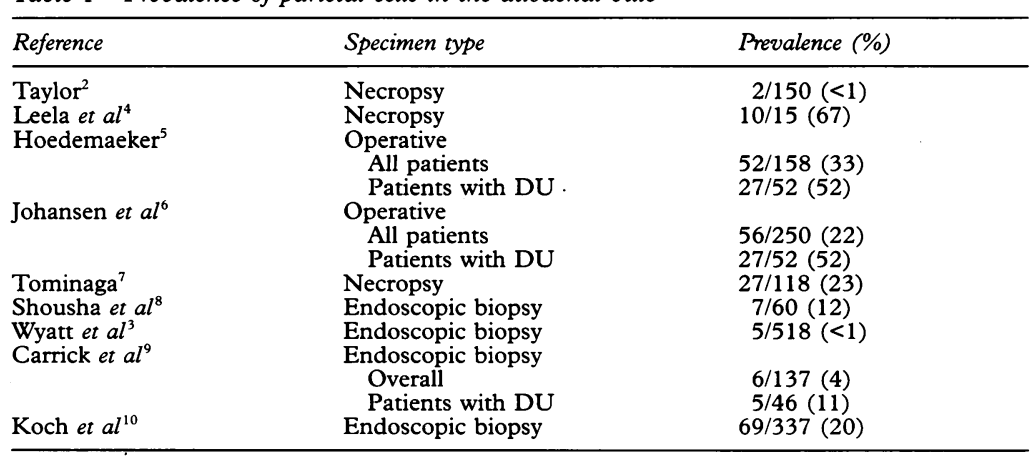

$\mathrm{DU}=$ duodenal ulcer.

Parietal cells in the proximal duodenum were first described by Kaufman in $1906^{1}$ and noted to be close to Brunner's glands. Further studies have shown their prevalence in the duodenal bulb to vary, ranging from less than $1 \%^{23}$ to almost $70 \%^{4}$ (table 1). Parietal cells were not found in the duodenum of the fetus and newborn, which suggests that they may be acquired. ${ }^{4}$ Most of these studies have described gastric heterotopia and not isolated groups of parietal cells in the duodenal bulb. Furthermore, there is some confusion in the literature regarding the difference between gastric heterotopia and gastric metaplasia in the duodenal bulb. The former refers to the presence of full thickness body-type gastric mucosa, and the latter, replacement of intestinal-type surface mucosa with gastric-type epithelium.

Widely reported variations in the prevalence of parietal cells in the duodenal bulb may be due to sampling error at endoscopy, or in the siting of the gastroduodenal junction. ${ }^{711} \mathrm{De}-$ tection of parietal cells may also be difficult by light microscopy on haematoxylin and eosin stained preparations. Complex trichrome and lectin stains have been used, but are time consuming and technically demanding.

The prevalence of parietal cells in the duodenal bulb has been reported to be higher in patients with duodenal ulcer disease. ${ }^{569}$ Johansen and Hansen ${ }^{6}$ found parietal cells in the proximal duodenum in $56(22 \%)$ of 250 gastrectomy specimens ( 52 duodenal ulcer, 55 gastric ulcer, 23 prepyloric ulcer, and 120 cancer), but in $27(52 \%)$ of 52 specimens taken from patients with duodenal ulcer $(p<0 \cdot 05)$. It has been suggested that production of acid by parietal cells in the duodenal bulb may contribute to the pathogenesis of duodenal ulcer. ${ }^{9}$ The relation between Helicobacter pylor infection, a major risk factor for duodenal ulcer, and parietal cells in the duodenal bulb has not been explored.

The aim of this study was to investigate the importance of duodenal parietal cells, rather than gastric heterotopia or gastric metaplasia, in the aetiology of duodenal ulcer. Prevalence of parietal cells in the duodenal bulb was determined in patients with duodenal ulcer and in healthy controls, with and without $H$ pylori infection. Four carefully sited samples were taken and a highly specific and sensitive monoclonal antibody directed against $\mathrm{H}^{+}, \mathrm{K}^{+}$ATPase (HK12.18) was used to identify parietal cells accurately.

\section{Methods}

Twenty six patients with endoscopically diagnosed duodenal ulcer were studied, 19 of 
Table 2 Clinical and demographic details of the subjects studied

\begin{tabular}{lllll}
\hline & Controls & \multicolumn{3}{l}{ Patients with DU } \\
\hline Endoscopy & Normal & Normal & DU & DU \\
H pylori status & Negative & Positive & Negative & Positive \\
No. of subjects & 10 & 6 & 7 & 19 \\
No. of men & 4 & 5 & 6 & 13 \\
Age in years mean (range) & $33(24-40)$ & $34(22-54)$ & $39(26-53)$ & $37(22-58)$ \\
Current smokers & 3 & 2 & 1 & 3 \\
\hline
\end{tabular}

$\mathrm{DU}=$ duodenal ulcer.

whom were positive for $H$ pylori infection. Six of the seven $H$ pylori negative patients had symptomatic and endoscopic recurrence of duodenal ulcer disease at least six months after eradication of $H$ pylori. The remaining $H$ pylori negative patient with duodenal ulcer had never been infected. Sixteen healthy controls (six $H$ pylori positive) with normal endoscopy were studied. None of the patients nor controls had taken non-steroidal anti-inflammatory drugs within one month, or antisecretory medication within two weeks of the study. Clinical and demographic details are given in table 2 .

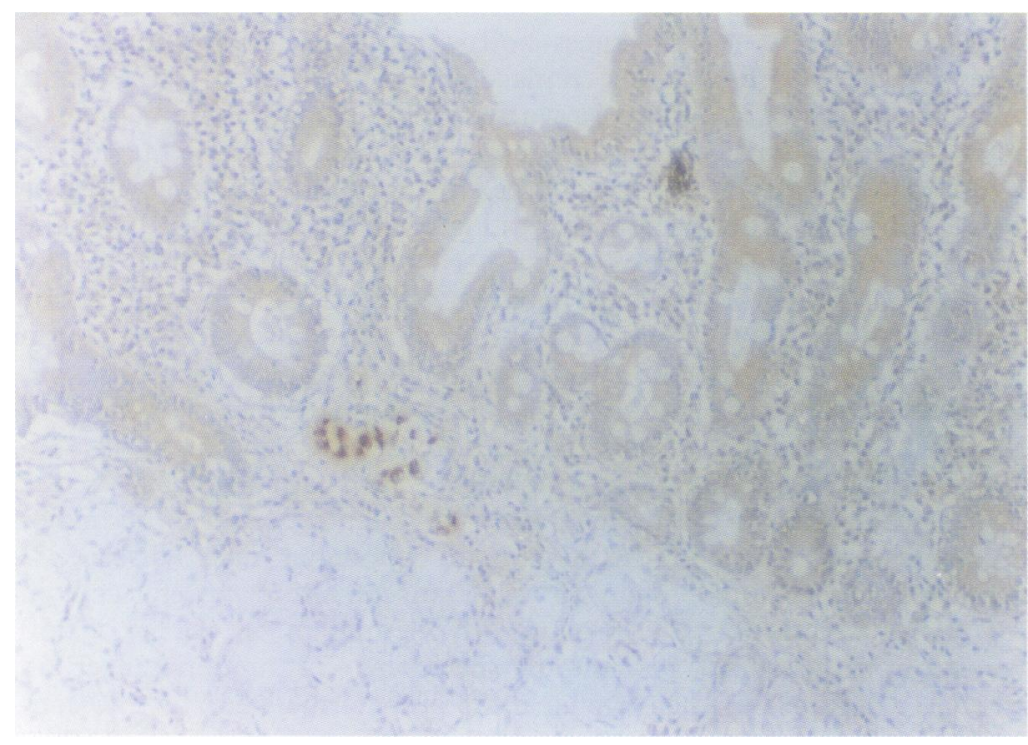

Figure 1 Duodenal bulb biopsy specimen stained with the monoclonal antibody directed against $\mathrm{H}^{+}, \mathrm{K}^{+}-$ATPase (HK12.18). Labelled parietal cells are stained brown.

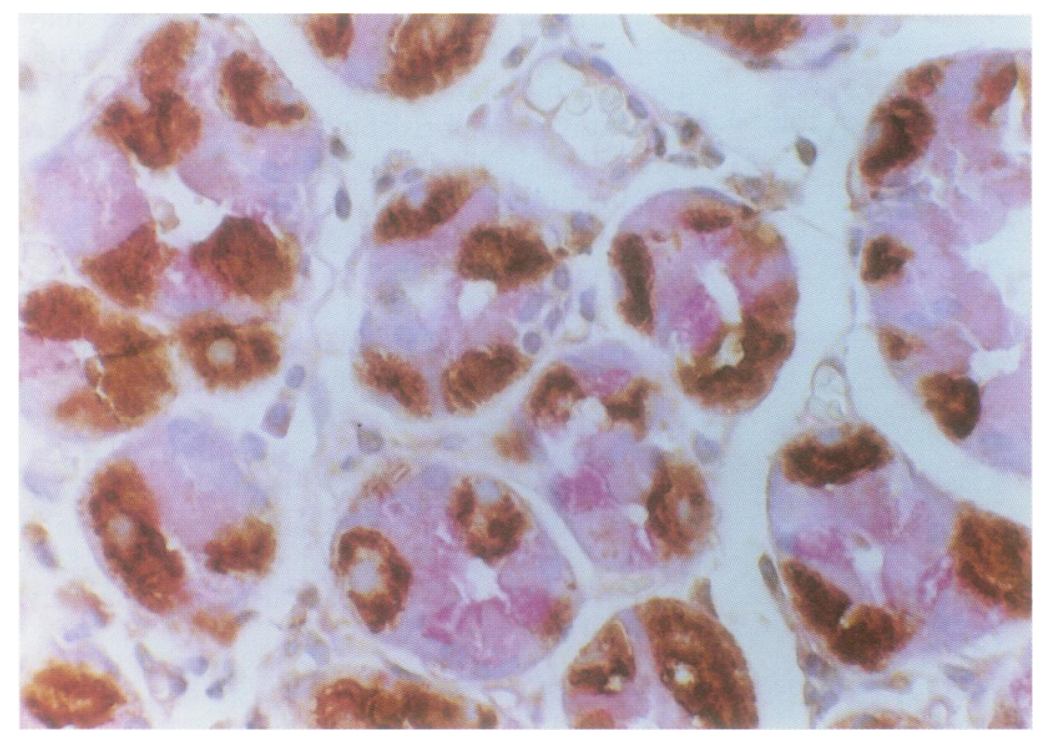

Figure 2 Gastric body biopsy specimen stained with the monoclonal antibody directed against $\mathrm{H}^{+}, \mathrm{K}^{+}-$ATPase (HK12.18). Labelled parietal cells are stained brown.

\section{DETERMINATION OF H PYLORI STATUS}

$H$ pylori status was determined by histology (antral, body and duodenal bulb biopsy specimens routinely processed and stained with haematoxylin and eosin and Gimenez stains), culture (antral and duodenal bulb biopsy specimens isolated in selective and non-selective media, and microaerobic conditions for up to 10 days) and by the ${ }^{13} \mathrm{C}$-urea breath test (European Standard Protocol, where a result is positive if excess $\delta^{13} \mathrm{CO}_{2}$ excretion exceeds 5 per $\mathrm{ml}^{12}$ ). Subjects were classified as $H$ pylori positive if they had a positive breath test and positive histology from any site or positive culture, or both. Absence of $H$ pylori was defined as failure to detect the bacterium in all three tests.

\section{IDENTIFICATION OF PARIETAL CELLS}

Murine monoclonal antibody $\mathrm{HK} 12.18$ was used as a specific marker for $\mathrm{H}^{+}, \mathrm{K}^{+}$-ATPase. $\mathrm{HK} 12.18$ raised against pig gastric microsomes enriched in $\mathrm{H}^{+}, \mathrm{K}^{+}$-ATPase was reconstituted from lyophilised mouse ascites with $250 \mu \mathrm{l}$ distilled water, aliquoted and stored at $-20^{\circ} \mathrm{C}$ until required.

Four endoscopic duodenal bulb biopsy specimens were taken with standard cupped forceps (Olympus FB23-35K, Japan) by one endoscopist, more than $1 \mathrm{~cm}$ away from the edge of any duodenal ulcer, and more than $1 \mathrm{~cm}$ from the pylorus. The biopsy specimens were placed immediately in formalin. After routine processing, $2 \mu \mathrm{m}$ sections were stained with HK12.18 using a modification of the peroxidase-antiperoxidase technique. ${ }^{13}$ After washing with water and phosphate buffered saline (PBS), the slides were incubated with HK12.18 (diluted 1 in 2500 ) at $4^{\circ} \mathrm{C}$ for 16 hours. They were then washed with PBS, and incubated for 30 minutes with peroxidase conjugated rabbit anti-mouse (dilution 1 in 300) sera (Sigma, Poole, Dorset, UK). Visualisation of the antigen $\left(\mathrm{H}^{+}, \mathrm{K}^{+}\right.$-ATPase $)$was achieved by adding diaminobenzidine tetrahydrochloride hydrogen peroxide (DAB) as the chromogen substrate, and counterstaining with haematoxylin (fig 1). Figure 2 shows a gastric body biopsy specimen stained in the same way.

The presence or absence and the number of parietal cells in one section taken from each biopsy specimen was assessed blindly by an experienced histopathologist. The number of parietal cells is expressed as the total number of parietal cells seen in the four biopsy sections from each subject.

STATISTICAL METHODS AND ETHICS

The $\chi^{2}$ test was used to compare the significance of differences between the groups, where $\mathrm{p}<0.05$ was regarded as statistically significant. The protocol was approved by Parkside ethical committee and all subjects gave written informed consent.

\section{Results}

The overall prevalence of parietal cells in the duodenal bulb in all subjects was $31 \%(13 / 42)$ 
Table 3 Prevalence of parietal cells in the biopsy specimens of the duodenal bulb in healthy controls and in patients with duodenal ulcer (DU)

\begin{tabular}{lllll}
\hline & Controls & \multicolumn{3}{c}{ Patients with $D U$} \\
\hline No. of subjects & 16 & & 26 \\
Parietal cells present (\%) & $4(25)$ & Positive & Negative & Positive \\
H pylori status & Negative & 6 & 7 & 19 \\
No. of subjects & 10 & $1(16)$ & $4(57)$ & $5(26)$ \\
Parietal cells present (\%) & $3(30)$ & $20(\mathrm{n}=1)$ & $7(5-20)$ & $7(5-15)$ \\
Median (range) number of & $6(4-7)$ & 20 parietal cells/subject & 6 &
\end{tabular}

(table 3). The prevalence of parietal cells in the duodenal bulb did not differ significantly $\left(\chi^{2}=0.66, p=0.4\right)$ between patients with duodenal ulcer disease (nine of 26) and healthy controls (four of 16). The prevalence of parietal cells in the duodenal bulb was similar in all subjects, regardless of $H$ pylori status (table 3 ). The median number of parietal cells in the duodenal bulb identified per subject was not significantly different between the four groups (table 3), with an overall median (range) of 7.5 (4-20) parietal cells/subject.

\section{Discussion}

\section{IDENTIFICATION OF PARIETAL CELLS}

Parietal cells, either isolated or in small clusters, may be difficult to identify using haematoxylin and eosin staining alone. We have used a highly specific and sensitive monoclonal antibody directed against $\mathrm{H}^{+}, \mathrm{K}^{+}$-ATPase $(\mathrm{HK} 12 \cdot 18)$ to identify parietal cells within duodenal biopsy specimens; this technique has not been applied before. Smolka et $a l^{1415}$ have confirmed the high specificity of HK12.18 in in vitro studies. The antibody has been shown to bind to the tubulovesicular membranes of the parietal cell cytoplasm. ${ }^{1415}$ Kelly et al ${ }^{16}$ used a monoclonal antibody directed against $\mathrm{H}^{+}, \mathrm{K}^{+}$-ATPase to map the distribution of parietal cells in the human fetal and infant stomach, and found that the site of monoclonal antibody binding corresponded precisely with the location of parietal cells as determined by staining with haematoxylin and eosin. Binding of a monoclonal antibody to vesicular membranes containing $\mathrm{H}^{+}, \mathrm{K}^{+}$-ATPase was demonstrated by Karlsson et al. ${ }^{17}$ The same group showed that the monoclonal antibody directed against $\mathrm{H}^{+}$, $\mathrm{K}^{+}$-ATPase did not bind to $\mathrm{Na}^{+}, \mathrm{K}^{+}$-ATPase containing vesicular membranes, confirming its high specificity for $\mathrm{H}^{+}, \mathrm{K}^{+}$-ATPase.

The high sensitivity of HK12.18 has been confirmed by Smolka $e t a l,{ }^{14}$ who demonstrated that the antibody bound to the tubulovesicular membranes of the parietal cell even after pretreatment with cimetidine, so that antibody binding was independent of the secretory state of the cell.

\section{PREVALENCE}

The overall prevalence $(31 \%)$ of parietal cells found in this study in the duodenal bulb is notably higher than in previous endoscopic studies, but in keeping with reports of necropsy and operative specimens (table 1). In the three largest studies of resected duodenal bulbs, parietal cells were found in $22-33 \%$ of cases. ${ }^{567}$
By contrast, in the endoscopic studies parietal cells were found in only $1-20 \%$ of subjects. ${ }^{3910}$ It has been reported that the prevalence of parietal cells in the duodenal bulb is higher in patients with duodenal ulcer than healthy subjects (table 1). ${ }^{569}$ Hoedemaeker $^{5}$ found parietal cells in $52 \%$ of patients with duodenal ulcer compared with $33 \%$ of those without duodenal ulcer disease $(\mathrm{p}<0 \cdot 05)$. Carrick et al, ${ }^{9}$ using two duodenal bulb biopsy specimens, found parietal cells more frequently in patients with duodenal ulcer than in healthy subjects, but the difference did not reach statistical significance. Using a highly specific method, we found that parietal cells were more common in the duodenal bulb in patients with duodenal ulcer than in healthy controls, but the difference was not statistically significant. According to our hypothesis, the difference in the prevalence of parietal cells in the duodenal bulb should have been largest between the $H$ pylori positive patients with duodenal ulcer and the $H$ pylori negative controls. However, the prevalence of parietal cells was similar between these two subgroups, with parietal cells seen in five (26\%) of $19 \mathrm{H}$ pylori positive patients with duodenal ulcer and in three $(30 \%)$ of $10 \mathrm{H}$ pylori negative controls. It is possible that our findings may be subject to a type II error-that is, the null hypothesis is not rejected when it is false. It would be necessary to study about 180 patients with duodenal ulcer and 180 controls to have a $90 \%$ power of achieving a significant result at the $5 \%$ level.

\section{HISTOLOGY}

Parietal cells were seen as single cells or in small clumps, and at most, in two of the four biopsy specimens from each subject (fig 1). The total number of parietal cells identified in the duodenal bulb biopsy specimens was small (median 7.5 per subject), and not significantly different between patients with duodenal ulcer and controls, or between $H$ pylori positive and negative subjects. The sparsity of the parietal cells in the duodenal bulb may contribute to the difference in the reported prevalence between the necropsy and operative studies using larger pieces of tissue and the smaller endoscopic biopsy specimens. We suggest that taking four directed biopsy specimens from each duodenal bulb successfully minimised the sampling error.

A possible criticism of some of the earlier studies is that the parietal cells found in the duodenal bulb may actually have been at the gastroduodenal junction. This junction is usually sharp, and is characterised not only by the abrupt transition from gastric mucosa to the characteristic villous epithelium of the duodenal mucosa, but also by the transition from the branched tubular pyloric glands to multilobular mucus Brunner's glands. ${ }^{7}$ However, this junction is not always sharply demarcated and there may be islands of intestinal mucosa on the gastric side of the junction and, more rarely, islands of gastric mucosa on the duodenal side. The gastroduodenal junction may be crenated with finger-like processes of gastric 
epithelium extending up to $6 \mathrm{~mm}$ into the duodenum. ${ }^{11}$ We therefore took the duodenal bulb biopsy specimens more than $10 \mathrm{~mm}$ distally from the pylorus in order to avoid sampling gastric mucosa.

\section{RELATION TO $H$ PYLORI INFECTION}

Because $H$ pylori infection is a major risk factor for duodenal ulcer, and because the prevalence of parietal cells in the duodenal bulb was purported to be higher in patients with duodenal ulcer, we investigated whether there was a relation between $H$ pylori infection and parietal cells in the duodenal bulb in patients with duodenal ulcer. Basal and stimulated acid outputs are higher in $H$ pylori positive patients with duodenal ulcer than in $H$ pylori negative controls. ${ }^{18}$ It was therefore possible that $H$ pylori may have a similar effect on local acid production within the duodenal bulb. We hypothesised that $H$ pylori infection in patients with duodenal ulcer would lead to an increase in the prevalence of parietal cells in the duodenal bulb: it did not. In fact, the prevalence and number of parietal cells in the duodenal bulb was not affected by $H$ pylori infection, either in healthy controls or in patients with duodenal ulcer.

\section{ROLE OF PARIETAL CELLS IN THE DUODENAL} BULB

It is not known why parietal cells are found in the duodenal bulb. Carrick et $a l^{9}$ demonstrated acid secretion within the duodenal bulb in patients with duodenal ulcer using Congo Red after stimulation with pentagastrin. Unfortunately, biopsy specimens were not taken from the apparent acid secreting areas (which turned Congo Red blue/black) to confirm that these sites did contain parietal cells, and that there was local acid secretion within the duodenal bulb. We had difficulty in replicating the Congo Red technique in patients with duodenal ulcer, because the often scarred and distorted duodenal bulb was not readily coated with the solution of indicator dye.

The parietal cells in the duodenal bulb identified with HK12.18 are probably functional, because they contain tubulovesicular membranes, which are an essential component of the acid secreting apparatus. ${ }^{141519}$ However, we are unable to comment on the functional activity of these structures.

The number of parietal cells seen in the duodenal biopsy specimens was small, with a median of $7 \cdot 5$ cells seen per subject. Cox $^{20}$ estimated that the normal adult stomach contains about $1 \times 10^{9}$ parietal cells. An endoscopic biopsy specimen of the gastric body contains about 120 cells $/ \mathrm{mm}^{2}$. It seems likely therefore that the amount of acid secreted by the small number of parietal cells in the duodenal bulb is negligible.

In conclusion, using multiple duodenal bulb biopsy specimens and a specific monoclonal antibody directed against $\mathrm{H}^{+}, \mathrm{K}^{+}$-ATPase to identify parietal cells, we have shown that these cells are found in the duodenal bulb in $31 \%$ of subjects. Their presence did not correlate with duodenal ulcer disease or $H$ pylori status. These findings do not support the hypothesis that parietal cells in the duodenal bulb contribute to the pathogenesis of duodenal ulcer.

We thank the nurses of the Endoscopy units at Central Middlesex and St Mary's Hospitals for their help. AWH is supported by a grant from Lederle Laboratories, UK, and AS is a recipien of grant DK 43138 from the National Institutes of Health, USA.

1 Miyagawa Y. The exact distribution of the gastric glands in man and certain animals. F Anat 1920;55:56-7.

2 Taylor AL. The epithelial heterotopias of the alimentary tract. F Pathol Bact 1927;30:415-49.

3 Wyatt Ji, Rathbone BJ, Sobala GM, Shallcross T, Heatley $\mathrm{RV}$, Axon ATR, et al. Gastric epithelium in the duodenum Its association with Helicobacter pylori and inflammation. f Clin Pathol 1990;43:981-6.

4 Leela K, Kanagasuntheram R. A microscopic study of the human pyloro-duodenal junction and proximal duodenum. Acta Anat 1968;71:1-12.

5 Hoedemaeker PJ. Heterotopic gastric mucosa in the duodenum. Digestion 1970;3:165-73.

6 Johansen A, Hart Hansen O. Heterotopic gastric epithelium in the duodenum and its correlation to gastric disease and
acid level. Acta Pathol Microbiol Scand 1973;81:676-80.

7 Tominaga K. Distribution of parietal cells in the antral mucosa of human stomachs. Gastrenterology $1975 ; 69$ :
munatrion 1201-7.

8 Shousha S, Spiller RC, Parkins RA. The endoscopically abnormal duodenum in patients with dyspepsia: biopsy findings in 60 cases. Histopathology 1983;7:23-34.

9 Carrick J, Lee A, Hazell S, Ralston M, Daskalopoulos G. Campylobacter pylori, duodenal ulcer and gastric metaplasia: possible role of functional heterotopic tissue in ulcerogenesis. Gut 1989;30:790-7.

10 Koch HK, Boemke S. Gastritis and Helicobacter pylori prevalence in patients with heterotopic gastric mucosa or gastric metaplasia in the duodenum. In: Pajares JM, et al. eds $H$. pylori and gastroduodenal pathology. Berlin, eds. H. pylor and gastroduodenal patholo

11 Lawson $\mathrm{HH}$. Definition of gastroduodenal junction in healthy subjects. $\mathcal{f}$ Clin Pathol 1988;41:393-6.

12 Logan RPH, Polson RJ, Misiewicz JJ, Rao G, Karim NQ, Newell D, et al. Simplified single sample ${ }^{13}$ Carbon urea breath test for Helicobacter pylori: comparison with histology, culture and ELISA serology. Gut 1991;32:1461-4.

13 Sternberger LA. Immunocytochemistry. New York: J Wiley and Sons, 1979.

14 Smolka A, Helander HF, Sachs G. Monoclonal antibodies against gastric $\mathrm{H}+-\mathrm{K}+$ ATPase. Am f Physiol 1983;245: G589-96.

15 Smolka A, Alverson L, Fritz R, Swiger K, Swiger F. Gastric H, K-ATPase topography: amino acids 888-907 are cytoH, K-ATPase topography: amino acids 888-907 are cyto-

plasmic. Biochem Biophys Res Commun 1991;180:1356-64.
16 Kelly EJ, Lagopoulos M, Primrose JN. Immunocytochemical localisation of parietal cells and G cells in cytochemical localisation of parietal cells and G cells
the developing human stomach. Gut 1993;34:1057-9.

17 Karlsson FA, Burman P, Loof L, Mardh S. Major parietal cell antigen in autoimmune gastritis with pernicious anaemia is the acid-producing $\mathrm{H}+, \mathrm{K}+$-adenosine triphosphatase of the stomach. $\mathcal{f}$ Clin Invest 1988;81:475-9.

18 El-Omar E, Penman I, Dorrian CA, Ardill JES, McColl KEL. Eradicating Helicobacter pylori infection lowers gastrin mediated acid-secretion by two thirds in patients with duodenal ulcer. Gut 1993;34:1060-5.

19 Soroka CJ, Chew CS, Hanzel DK, Smolka A, Modlin IM G IM, Goldring DR. Characterization of membrane and cytoskeletal compartments in cultured parietal cells; imEur 7 Cell Biol 1993;60:76-87.

20 Cox AJ. Stomach size and its relation to chronic peptic ulcer. Arch Pathol 1995;54:407-22. 